\title{
Front Matter: Volume 11772
}

, "Front Matter: Volume 11772," Proc. SPIE 11772, Optical Sensors 2021, 1177201 (14 May 2021); doi: 10.1117/12.2599008

SPIE. Event: SPIE Optics + Optoelectronics, 2021, Online Only 


\section{PROCEEDINGS OF SPIE}

\section{Optical Sensors 2021}

Francesco Baldini

Jiri Homola

Robert A. Lieberman

Editors

19-23 April 2021

Online Only, Czech Republic

Sponsored by

SPIE

Cooperating Organisations

ELI Beamlines (Czech Republic)

Laserlab Europe

European Optical Society

HiLASE Centre (Czech Republic)

Published by

SPIE 
The papers in this volume were part of the technical conference cited on the cover and title page. Papers were selected and subject to review by the editors and conference program committee. Some conference presentations may not be available for publication. Additional papers and presentation recordings may be available online in the SPIE Digital Library at SPIEDigitalLibrary.org.

The papers reflect the work and thoughts of the authors and are published herein as submitted. The publisher is not responsible for the validity of the information or for any outcomes resulting from reliance thereon.

Please use the following format to cite material from these proceedings:

Author(s), "Title of Paper," in Optical Sensors 2021, edited by Francesco Baldini, Jiri Homola, Robert A. Lieberman, Proc. of SPIE 11772, Seven-digit Article CID Number (DD/MM/YYYY); (DOI URL).

ISSN: 0277-786X

ISSN: 1996-756X (electronic)

ISBN: 9781510643789

ISBN: 9781510643796 (electronic)

Published by

SPIE

P.O. Box 10, Bellingham, Washington $98227-0010$ USA

Telephone +1 3606763290 (Pacific Time)

SPIE.org

Copyright @ 2021 Society of Photo-Optical Instrumentation Engineers (SPIE).

Copying of material in this book for internal or personal use, or for the internal or personal use of specific clients, beyond the fair use provisions granted by the U.S. Copyright Law is authorized by SPIE subject to payment of fees. To obtain permission to use and share articles in this volume, visit Copyright Clearance Center at copyright.com. Other copying for republication, resale, advertising or promotion, or any form of systematic or multiple reproduction of any material in this book is prohibited except with permission in writing from the publisher.

Printed in the United States of America by Curran Associates, Inc., under license from SPIE.

Publication of record for individual papers is online in the SPIE Digital Library.

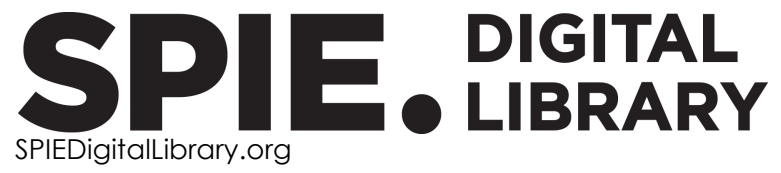

Paper Numbering: A unique citation identifier (CID) number is assigned to each article in the Proceedings of SPIE at the time of publication. Utilization of CIDs allows articles to be fully citable as soon as they are published online, and connects the same identifier to all online and print versions of the publication. SPIE uses a seven-digit CID article numbering system structured as follows:

- The first five digits correspond to the SPIE volume number.

- The last two digits indicate publication order within the volume using a Base 36 numbering system employing both numerals and letters. These two-number sets start with 00, 01, 02, 03, 04, $05,06,07,08,09,0 A, 0 B \ldots$. OZ, followed by 10-1Z, 20-2Z, etc. The CID Number appears on each page of the manuscript. 


\section{Contents}

ADVANCED COMPONENTS FOR SENSING

1177206 A monolithically integrated micro fluidic channel in a silicon-based photonic-integrated-circuit technology for biochemical sensing [11772-3]

$1177207 \quad$ Stabilizing Brillouin fiber laser for applications in distributed BOTDA sensing [1 1772-4]

$11772 \mathrm{OB} \quad 3 \mathrm{D}$ depth sensing of active structured light field based on EPI [11772-8]

\section{CHEMICAL SENSING}

11772 OC Micro-opto-fluidic platform for spectroscopic identification of water-based fluids [11772-9]

11772 OE Nanoporous silver films produced by solid-state dewetting for SERS applications [11772-11]

11772 Ol Detection of copper by localized surface Plasmon resonance based fiber optic technique [11772-15]

\section{PHYSICAL SENSING}

$117720 \mathrm{~J} \quad$ Geo-localization using indoor visible light communication [1 1772-16]

11772 OK Vehicular visible light communication in a traffic controlled intersection [11772-17]

$11772 \mathrm{OL} \quad$ Determination of Stokes velocities and sedimentation rate by a photonic resonant surface signal [11772-18]

FIBER OPTIC SENSORS

$1177200 \quad$ Fibre Bragg grating inscription into a seven core fibre and its application as a vector bending sensor (Invited Paper) [11772-21]

11772 OP Using supervised deep-learning to model edge-FBG shape sensors: a feasibility study [1 1772-22]

$117720 Q \quad$ Real time and label-free detection of C-reactive protein in serum by long period grating in double cladding fiber [11772-23] 
11772 OR Lab-on-fiber SERS optrodes for biomedical applications [11772-24]

11772 OS TFBG-assisted fiber optic sensors for environmental monitoring [11772-25]

11772 OT High sensitivity optical fiber microring sensor based on Whispering-Gallery mode for water analysis [11772-26]

11772 OU Multi U-bent cladded POF sensors for refractive index measurement [1 1772-27]

$117720 \mathrm{~V}$ Optimization of the geometries of palladium-coated single mode tapered fiber hydrogen sensors for improving sensitivity [11772-28]

\section{NOVEL CONCEPTS IN OPTICAL SENSING}

11772 OY Ultrasensitive surface refractive index imaging in all-dielectric structures (Invited Paper) [11772-31]

$117720 Z \quad$ Nanometer-scale cavities for mid-infrared light based on graphene plasmons [11772-32]

1177210 Surface-enhanced sensitivity from tunable plasmonic nanostructures arrays [11772-33]

1177212 A feasibility study for self-heterodyne earth satellite dual-comb spectroscopy [11772-35]

1177213 Pore size assessment of nanoporous alumina using absorption of laser light [11772-36]

1177214 Temperature tunable whispering gallery modes laser based on a capillary tube [11772-37]

1177215 Phase-frequency time-gated reflectometry for absolute measurements [11772-38]

1177217 Mid-infrared laser-based detection of benzene [11772-40]

\section{POSTER SESSION}

1177218 Innovation of detecting optimized intensity of light via three-dimensional material rendering [11772-41]

1177219 A simple and reliable counting and display circuit for laser rangefinder [11772-42]

11772 1C Electro-optical measuring system for quality assurance of novel nanowire surfaces [11772-45]

11772 1D Diagnostics of the combustion process of gaseous hydrocarbon fuel by methods of applied optical spectroscopy [11772-46]

iv 
11772 lE Monitoring of polarization-based effects in fiber-optic transmission link caused by environmental variations [11772-47]

$117721 \mathrm{G}$ Chromium-doped borate glass ceramics for optical temperature sensors [11772-49]

$117721 \mathrm{H} \quad$ Towards Czech national research infrastructure for Clock Network Services [11772-50]

$117721 \mathrm{~J}$ Optical spectral device based on an acoustooptic tunable filter with a frequency-hopping change of the control signal [11772-52]

$117721 \mathrm{~L} \quad$ Numerical analysis of CZTSSe solar cell with different BSF layers for performance improvement [11772-54]

$117721 \mathrm{M}$ Temperature effect on spectral properties of cesium lead bromide perovskite nanocrystals in borogermanate glass [11772-55]

1177210 Principles of experimental research of sensitivity inhomogeneity of matrix sensors [11772-57]

11772 is Single-particle sensing capabilities of cylindrical microresonators based on optical fibers [11772-61]

$117721 \mathrm{~V}$ Location and wayfinding services through visible light in crowded buildings [1 1772-64]

$117721 \mathrm{~W}$ On-board two-position optical system of classification and determination of trajectory coordinates of objects in video stream [11772-65]

1177212 An ultra-broadband frequency response fiber vibration sensor based on single-mode-fewmode fiber coupler [11772-68]

1177220 The evaluation of various designs for ytterbium-doped fiber-based superfluorescent source at $1 \mu \mathrm{m}$ wavelength [11772-69]

$1177221 \quad$ Raman spectroscopy to investigate gallium nitride light emitting diodes after assembling onto copper substrates [11772-70]

1177222 Polarization-OTDR-based optical fibre sensor for plasma current measurement in ITER: effect of fibre bending, twisting and temperature dependence of Verdet constant on the measurement accuracy [11772-71]

1177223 High-speed sampling strategy for photoacoustic tomography using ROMP compressed sensing algorithm [11772-72]

1177224 Analysis of the shaft behaviour in aircraft engines using tip clearance data and custom designed laser sensors [11772-73]

1177226 Research of UV radiometer based on fiber spectroradiometer [11772-75]

1177227 Design of the optical system for 171-ytterbium single-ion optical clock [11772-77] 
1177229 Plasmon polarized spectra on gold films modified with femtosecond laser induced surface structures [11772-79]

11772 2B Fast-detection photoacoustic tomography platform based on GPSR compressed sensing [11772-81] 